\begin{tabular}{|c|c|c|c|c|c|}
\hline & 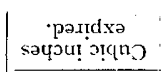 & 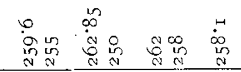 & 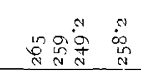 & 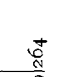 & \multirow{2}{*}{$\begin{array}{l}\text { The table in the adjoining column shows, in each case, the } \\
\text { number of instances examined, and the averages calculated from } \\
\text { them. } \\
\text { R. J. HORTON-SMITH. }\end{array}$} \\
\hline & saser jo $0^{\circ} \mathrm{N}$ & 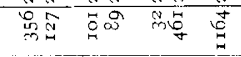 & 5 कै० & $\infty$ & \\
\hline \multirow{6}{*}{ 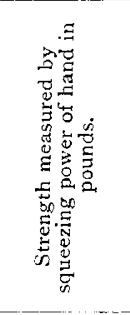 } & 'นеә $\mathbf{N}$ & 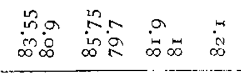 & 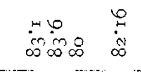 & $\overbrace{\infty}^{n}$ & \multirow{29}{*}{ 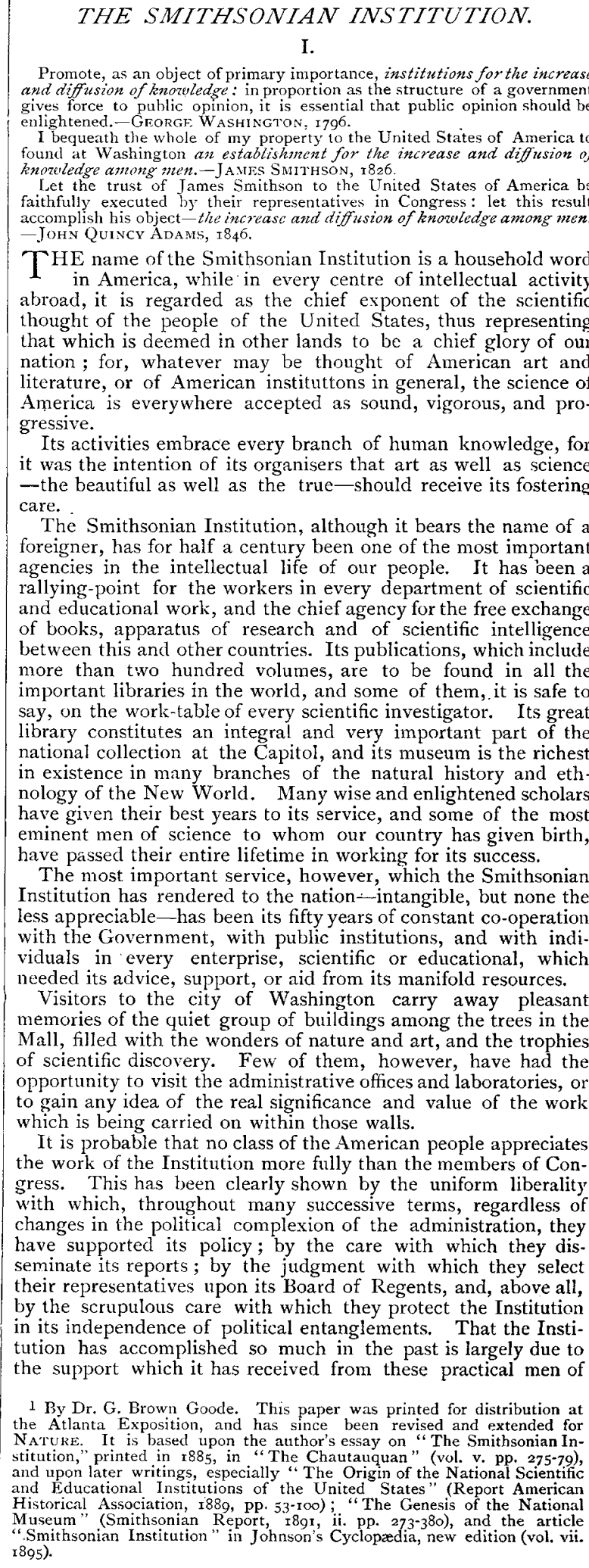 } \\
\hline & & & & & \\
\hline & риеч туәТ & & is & $\begin{array}{l}\dot{1} \\
\infty\end{array}$ & \\
\hline & saseo jo ${ }^{\circ} \mathrm{N}$ & & 兽 & \& & \\
\hline & •риеч әчві! & 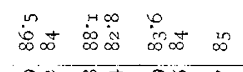 & 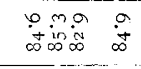 & $\begin{array}{l}\infty \\
\text { in } \\
\infty\end{array}$ & \\
\hline & sasej jo $0^{\circ}$ & in & sio & \& & \\
\hline \multirow{3}{*}{ 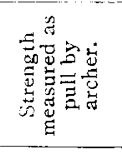 } & 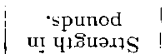 & & $n=$ m & & \\
\hline & 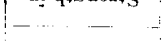 & & & के & \\
\hline & $\cdot \operatorname{saseajo}{ }^{\circ} \mathrm{N}$ & 学骂 & ric in & $\hat{a}$ & \\
\hline \multirow{7}{*}{ 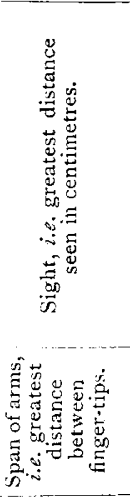 } & 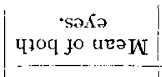 & 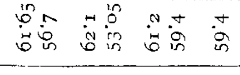 & 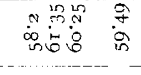 & $\ddot{0}$ & \\
\hline & •əКә נәәТ & 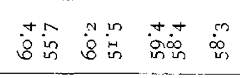 & 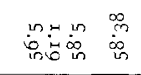 & है & \\
\hline & 'sasej jo $\circ \mathbf{O}$ & 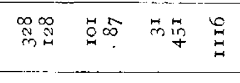 & 必 品 & & \\
\hline & ${ }^{2}$ ә $ә$ & on in in & 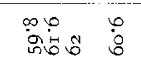 & in & \\
\hline & $\cdot \operatorname{sasea~jo~} \mathrm{o}^{\mathrm{N}}$ & 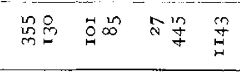 & $\infty$ in $8 \underset{\substack{\infty\\
}}{\infty}$ & ळ & \\
\hline & $\begin{array}{l}\text { 'səqวu! } \\
\text { u! uedS }\end{array}$ & 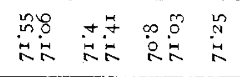 & 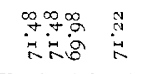 & 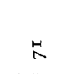 & \\
\hline & 'saseo jo ${ }^{\circ} \mathrm{N}$ & 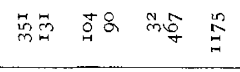 & $\therefore 88$ & 2 & \\
\hline \multirow{4}{*}{ 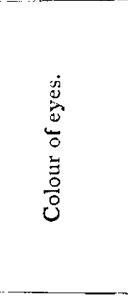 } & 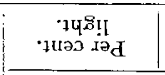 & 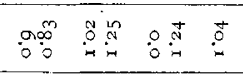 & $\circ: \frac{\text { n }}{\circ}=$ & $\because$ & \\
\hline & 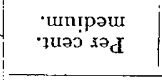 & 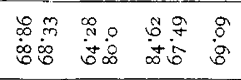 & 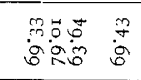 & $\because$ & \\
\hline & 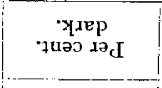 & 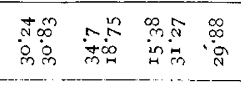 & 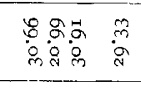 & 8 & \\
\hline & sases jo & 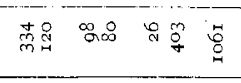 & ND in $\underset{\hat{d}}{0}$ & 2 & \\
\hline \multirow{2}{*}{ 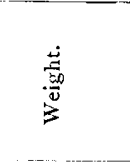 } & $\begin{array}{c}\text {-spunod } \\
\text { u! } 348 \div 9 \mathrm{M}\end{array}$ & 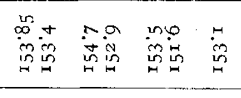 & 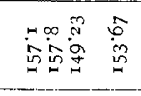 & $\stackrel{a}{i n}$ & \\
\hline & әseว jo o $\mathrm{o}$ & 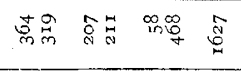 & 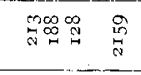 & $\infty$ & \\
\hline \multirow{2}{*}{ 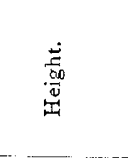 } & 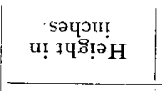 & 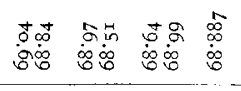 & 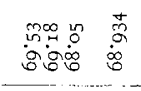 & $\hat{\dot{g}}$ & \\
\hline & 'sasea jo ${ }^{\circ} \mathrm{O}$ & 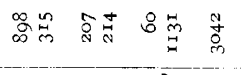 & 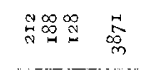 & $\hat{\alpha}$ & \\
\hline \multirow{2}{*}{ 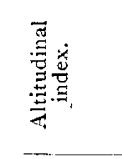 } & ·әрии & 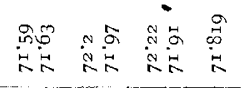 & 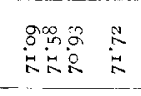 & $\stackrel{\substack{+\\
}}{\sim}$ & \\
\hline & sases yo $\circ^{\circ} \mathrm{N}$ & 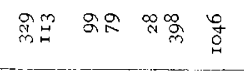 & ㅁo & 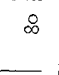 & \\
\hline \multirow{3}{*}{ 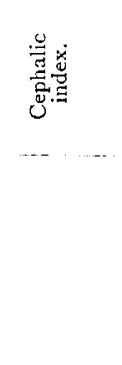 } & $\cdot$ xәри & 吾 & 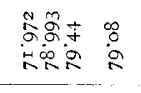 & $\stackrel{2}{a}$ & \\
\hline & & 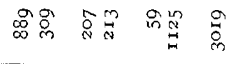 & 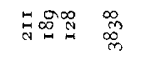 & a & \\
\hline & & 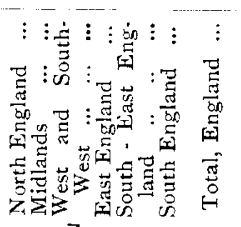 & 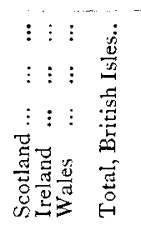 & 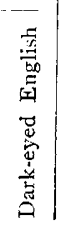 & \\
\hline
\end{tabular}

NO. I 368 , vOL. 53 ] 
business, and through them from the people of the United States; since the comparatively small income of the Institution has been made a nucleus for very considerable annual appropriations granted by the United States Congress, for the support of the manifold interests the administration of which have been entrusted to it. It is to such support that it will owe its efficiency in the future, and it seems right that every opportunity should be taken to explain its operations to the public. No intelligent American can fail to appreciate the benefits which the highest interests of the American people receive through the proper administration of the Smithsonian bequest.

The ORigin OF the Institution.

The story of the foundation of the Smithsonian Institution sounds more like romance than fact. It seems like the fulfilment of some prophecy, and all the more so because of the promise of the future.

The father of the founder of the Smithsonian Institution, in early life known as Sir Hugh Smithson, was one of the most distinguished members of the English peerage. Upon the plate of his coffin in Westminster Abbey, where he was buried " in great pomp" in I786, he was described as "the most high, puissant and most noble prince Hugh Percy, Duke and Earl of Northumberland, Earl Percy, Baron Warkworth and Lovaine,

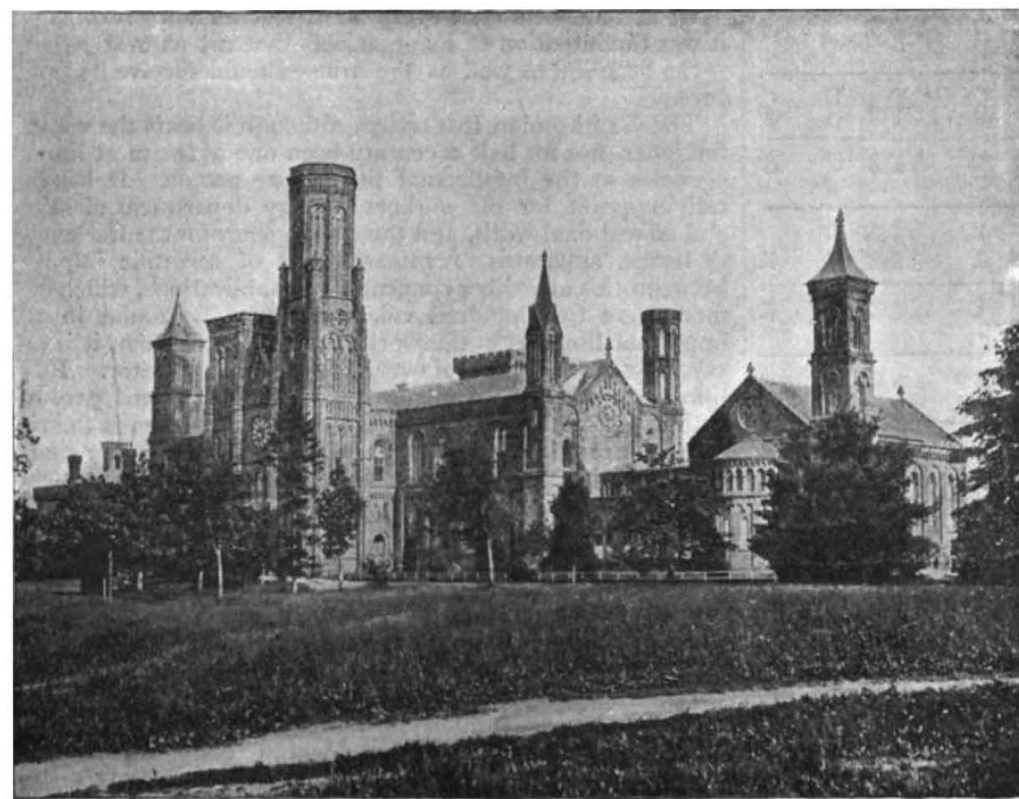

FIG. I.-The Smithsonian Building.

Lord Lieutenant and Custos Rotulorum of the Counties of Middlesex and Northumberland and of all America, one of the Lords of his Majesty's most Honourable and Privy Council, and Knight of the most noble Order of the Garter, \&c., \&c., \&c."

While his aged father was supporting this overwhelming burden of honours and dignities, and while his half-brother, Earl Percy, was serving as a Lieutenant-General in the war against the rebellious British colonies in North America, ${ }^{1}$ James Smithson, a youth of modest fortune, was acquiring the rudiments of a scientific education in English schools and colleges. He received the degree of Master of Arts from Pembroke College, Oxford, in 1786 , the year of his father's death. He was then known as James Lewis Macie, for he did not assume the name of Smithson until several years later, after he had attained to some reputation as a man of science. His mother was not the Duchess of Northumberland, but her cousin, Elizabeth Keate Macie, of Weston, near Bath (widow of James Macie), greatgranddaughter of Sir George Hungerford of Studley, and his wife, Lady Frances Seymour, sister of the sixth Duke of

1 Lord Algernon Percy, afterwards Duke of Northumberland, commanded the reinforcements at the battle of Lexington in 1775 , and led the column which reduced Fort Washington, near New York, in 1776

NO. I 368 , VOL. 53]
Somerset and aunt of Algernon Seymour, Lord Percy, whose daughter Sir Hugh Smithson married, and was thus enabled to assume the name of Percy and the title of Duke of Northumberland.

The Smithsons were an old Yorkshire family; Sir Hugh, the great.grandfather of James Smithson, having been created baronet by Charles II. in 1660.

James Smithson was undoubtedly proud of his illustrious ancestry, for in his will he described himself as "son of Hugh, first Duke of Northumberland and Elizabeth, heiress of the Hungerfords of Studley, and niece of Charles, the Proud Duke of Somerset."

He was, however. a man of broad, philosophic mind, and his training in the best scientific methods of his day, and association with leading investigators in Germany and France, and with his brother Fellows of the Royal Society of London, had developed in his mind a generous appreciation of the value of scholarship and scientific culture, and of the still greater importance which these were to have in coming years.

"The best blood of England flows in my veins," he once wrote; " on my father's side I am a Northumberland, on my mother's I am related to kings, ${ }^{2}$ but this avails me not. $M y$ name shall live in the memory of man when the titles of the Northumberlands and the Percys are extinct and forgotten.

These words seem little less than prophetic. The founder of the Smithsonian Institution has already earned perpetual fame.

The names of the successive Dukes of Northumberland, his kinsmen, have, as a rule, been little known outside Great Britain, though several of them have been munificent patrons of science.

Smithson seems, early in life, to have come fully into harmony with the scientific spirit of his time. In 1784 , while still an undergraduate at Oxford, he made a scientific exploration of the coasts of Scotland in company with a party of geologists. In 1787 he was admitted a Fellow of the Royal Society, and during the remaining forty-two years of his life, in Berlin, Paris, Rome, Florence, and Geneva, he was an associate of the leading men of science, and devoted himself to research. $\mathrm{He}$ made an extensive collection of minerals, which was destroyed by the burning of a portion of the Smithsonian building in I865, and he always carried with him in his travels a portable laboratory for chemical research.

His contributions to science are included in twenty-seven memoirs, chiefly upon topics in mineralogy and organic chemistry, though some of them relate to applied science and the industrial arts. His work, thongh not of an epoch-making character, was remarkable for its minute accuracy.

Smithson was a greater man than is indicated by his publishet writings alone. Berzelius declared that he was one of the most accomplished mineralogists in all Europe.

He was a man of generous culture who understood thoroughly the needs of the world in the direction of scientific endowment,

${ }^{1}$ Smitbson was born in France in $x_{7} 65$. The date 1754 usually given for his birth and engraved upon his tomb is wrong, as is shown by his Oxford matriculation records. The source of his fortune is not certainly known. At Oxford, where he was entered as a Gentleman Commoner, he wa understood to have succeeded to the estate of his mother's husband, Macie, and in $\mathrm{J}_{704}$ he received a bequest of $\oint_{3000}$ from his half-sister, Dorothy Percy. The major portion of his estate, however, came to him by the bequest of his half-brother, Colonel Henry Louis Dickinson, of the $84^{\text {th }}$ Request of his half-brother, Colonel Henry Louis Dickinson, of the $84^{\text {th }}$ that his mother was " died in Paris in 1820 . The statement of Smithson that his mother was " heiress of the Hungerfords of Studley," probably indicates the source of a consi

2 Smithson was of royal descent, through his maternal ancestor, the illfated Lady Catharine Grey, great-granddaughter of King Henry VII., fated Lady Catharine Grey, great-granddaughter of King Henry VII,
grandniece of Henry VIII., and cousin of Elizabeth. His ancestor in the grandniece of Henry VIII., and cousin of Elizabeth. His ancestor in the
ninth generation, Edward Seymour, the first Duke of Somerset and Protector ninth generation, Edward Seymour, the first Duke of Somerset and Protectn
of England, was the brother of Queen Jane Seymour and the uncle of King Edward VI. 
and his action in bequeathing his estate to the people of America was deliberate and well considered.

In that admirable little monograph entitled "Smithson and his Bequest," Mr. W. J. Rhees has pointed out that the tendency of the time of Smithson was towards the establishment of permanent scientific institutions. Between 1782 and 1826 , over twenty of the most important academies and societies now in existence were organised. "This period," he writes, " was not less marked by the gloom occasioned by long, protracted and almost universal war, and the extent and rapidity of its sociai changes, than by the lustre of its brilliant discoveries in science, and its useful inventions in the arts. Pure science had many illustrious votaries, and the practical application of its truths gave to the world many of the great inventions by means of which civilisation has made such immense and rapid progress." In support of these statements he quotes the words of Lord Brougham, who said that " to instruct the people in the rudiments of philosophy would of itself be an object sufficiently brilliant to allure the noblest ambition."

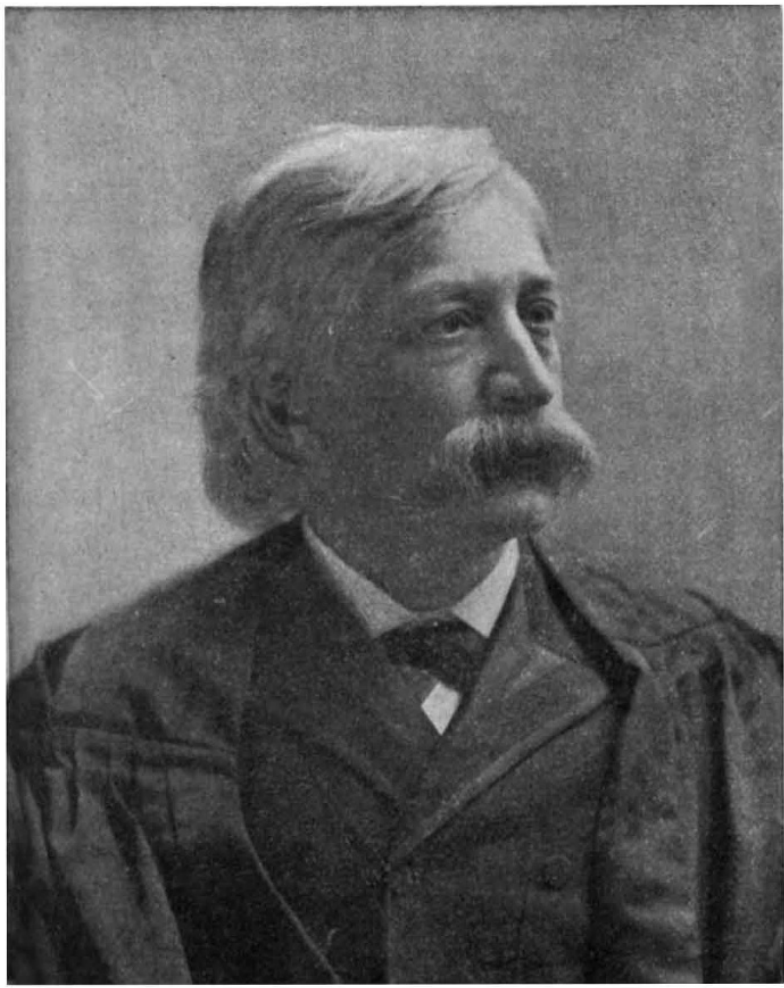

FIG. 2. - Chief Justice Fuller, Chancellor of the Smithsonian Institution.

Brougham forcibly recommended this idea to the wealthy men of England, pointing out that by the promotion of such ends, a man, however averse to the turmoil of public affairs, might enjoy the noblest gratification of which the most aspiring nature is susceptible, and influence by his single exertions the fortunes of a whole generation.

Very closely do these thoughts correspond to those expressed by Smithson in various passages in his note-books, and especially with that which is used for a motto upon the publications of the Institution :-

"Every man is a vahuable nember of society, who by his observations, researches, and experiments, procures knowledge for men."

Another sentence of his is still more pregnant with meaning. It is this :-

"It is in his knowledge that man has found his greatness and his happiness, the high superiority which he holds over the other animals who inherit the earth with him, and consequently, no ignorance is probably without loss to him, no error without evil."

NO. I 368, VOL. 53]
It was with a mind full of such thoughts as these, with perhaps the support and inspiration of Lord Brougham's words quoted above from his "Treatise on Popular Education," printed in 1825 , with such models in mind as the Royal Society, whose object is " the improvement of natural knowledge," the Royal Institution "for diffusing the knowledge and facilitating the general introduction of useful mechanical inventions and improvements, and for teaching the application of science to the common purposes of life," and the Society for the Diffusion of Useful Knowledge, established in London in 1825 , that in 1826 Smithson drew up his will, containing this most significant provision :-

"I BEQUEATH THE WHOLE OF MY PROPERTY TO THE UNITED STATES OF AMERICA TO FOUND AT WASHINGTON, UNDER THE NAME OF THE SMITHSONIAN INSTITUTION, AN ESTABLISHMENT FOR THE INCREASE AND DIFFUSION OF KNOWLEDGE AMONG MEN."

There is no reason known why he should have selected the United States as the seat of his foundation, though it is certain

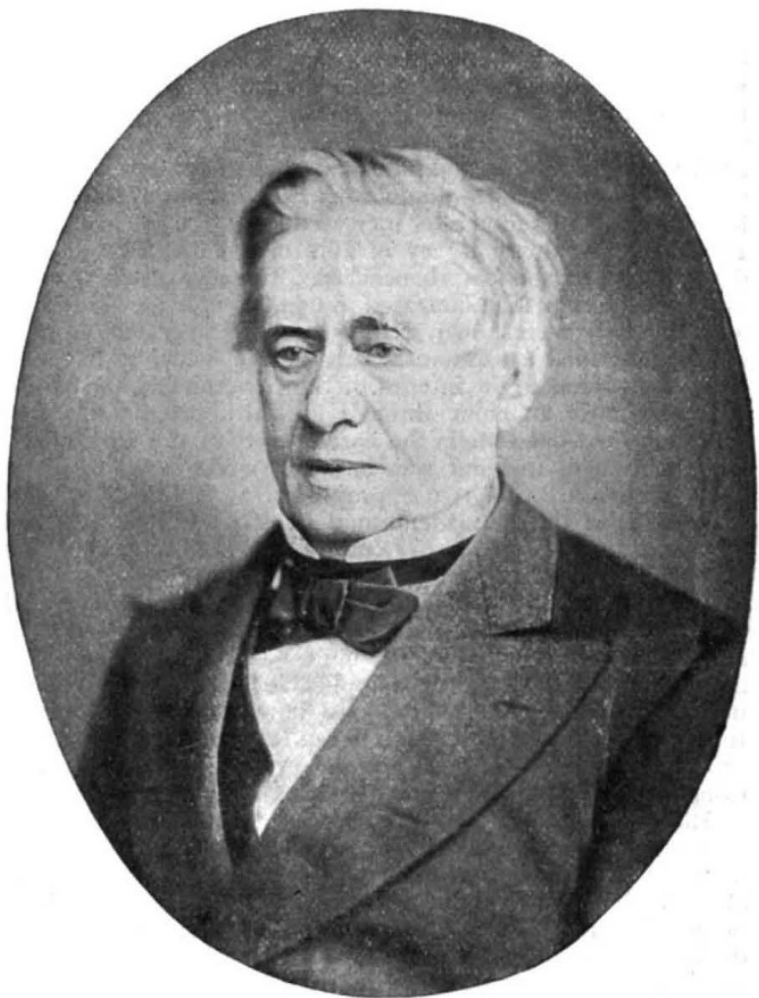

FIr. 3.-Joseph Henry, First Secretary of the Smithsonian Institution, I $846 \cdot 78$.

that he was in full sympathy with republican governments and the liberty of the people. His library contained only two books relating to America. Rhees quotes from one of these, "Travels Through North America," by Isaac Weld, secretary of the Royal Society, a paragraph concerning Washington, then a small town of 5000 inhabitants, in which it is predicted that "the Federal city, as soon as navigation is perfected, will increase most rapidly, and that at a future day, if the affairs of the United States go on as prosperously as they have done, it will become the grand emporium of the West, and rival in magnitude and splendour the cities of the whole world."

It is probable that he knew Joel Barlow in Paris, and was familiar with his plan for a realisation of Washington's project for a great national institution of learning in the Federal city.

Inspired by a belief in the future greatness of the new nation, realising that while the needs of England were well met by existing organisations such as would not be likely to spring up for many years in a new, poor, and growing country, Smithson founded in the new England an institution of learning, the civilising power of which has been of incalculable value. Who 
can attempt to say what the condition of the United States would have been to-day without his bequest? Well did John Quincy Adams say :-

" Of all the foundations of establishments for pious or charitable uses which ever signalised the spirit of the age or the com. brehensive beneficence of the founder, none can be named more deserving the approbation of mankind."

In I835, six years after Smithson's death, the United States legation in London was notified that his estate, amounting in value to about $£ \mathrm{r} 00,000$, was held in possession of the accountant-general of the British Court of Chancery.

As soon as the facts became public, great opposition to the acceptance of the gift arose in Congress. Eminent statesmen, led by Calhoun and Preston, argued that it was beneath the dignity of the United States to receive presents, and that the donor was seeking immortality for too moderate an equivalent. The wise counsels and enthusiastic labours of John Quincy Adams, who seems to have had from the first a thorough ap. preciation of the importance of the occasion, finally prevailed, and the Honourable Richard Rush was sent to England to prosecute the claim. He entered a friendly suit in the Courts of Chancery in the name of the President of the United States, and obtained, in less than two years, an event unparalleled in the history of Chancery, a favourable decision. The legacy was brought over in the clipper ship Mediator, in the form of 104,960 gold sovereigns. These were delivered September I, 1838, to the Philadelphia Mint, and immediately recoined into American money, yielding $508,3 \mathrm{I} 8.46$ dols. as the first instalment of the legacy. This was soon after increased to 515,169 dols., and in 1867 , by a residuary legacy of $26,210.63$ dols., the total sum derived from the founder's beneficence, which by careful management had been in 1867 increased to 650,000 dols., a sum which, as has already been shown, derives its significance, not from its own magnitude, but from the manner in which it has been utilised to stimulate the interest of the Government, and to draw to itself larger amounts through special appropriations from Congress. At one time in the early history of the Institution a large portion of its fund was in certain State honds which became worthless. Congress appropriated money to make good the loss, and the permanent fund, which, swelled by recent bequests, now amounts to 911,000 dols., is held as a deposit at 6 per cent. in the United States Treasury.

For eight years the original legacy lay in the Treasury, while the wise men of the nation tried to decide what to do with it. At the time, the adage that in a multitude of counsellors there is wisdom, did not appear to be applicable ; yet the delay, though irksome to those who desired to see immediate results, proved to be the best thing for the interests of the trust. Every imaginable disposition of the legacy was proposed and discussed in Congress; the debates fill nearly three hundred and fifty pages of Rhees' compilation of Smithsonian documents. Hundreds of letters advisory, expostulatory, and dissuasive were received from representative thinkers and from societies at home and abroad. Every man had a scheme peculiar to himself, and opposed all other schemes with a vigour proportionate to their dissimilarity to his own. Schools of every grade, from a national university to an agricultural school, a normal school and a school for the blind, were proposed. A library, a botanical garden, an observatory, a chemical laboratory, a popular publishing house, a lecture lyceum, an art museum, any and all of these and many more were proposed and advocated by this voluntary congress of many men of many minds.

\section{The Three Secretaries.}

The successful organisation of the Institution has been the result of long-continued effort on the part of men of unusual ability, energy, and personal influence. No board of trustees or regents, no succession of officers serving out their terms in rotation could have developed from a chaos of conflicting opinions, a strongly individualised establishment like the Smithsonian Institution. Especially effective in this respect has been the influence of the three men who have in succession held the office of "Secretary." The name of "Secretary," it should be stated, is that which in Washington designates the highest grade of executive responsibility. The Secretary of the Institution makes all appointments on the staff, is responsible for the expenditure and disbursement of all funds, is the legal custodian of all its property, and, ex officio, its librarian and the keeper of its museum.

NO. I 368 , VOI.. 53]
The names of Henry and Baird are so thoroughly identified with the history of the Institution during its first four decades, that their biographies would together form an almost complete history of its operations. A thirty-two years' term of uninterrupted administrative service was rendered by one, thirty-seven years by the other. Perhaps no other organisation has had the benefit of so uninterrupted an administration of forty years, beginning with its birth and continuing in an unbroken line of consistent policy a career of growing usefulness and enterprise.

The first meeting of the Board of Regents took place on September 7, I846, and before the end of the year the policy of the Regents was practically determined upon, for, after deciding upon the plan of the building now occupied, they elected to the secretaryship Prof. Joseph Henry, and thus approved his plan for the organisation of the Institution which had previously been submitted to them.

Henry was a man greatly distinguished in science through his epoch-making discoveries, which had already given to the world the electro-magnetic telegraph, and which form the foundation

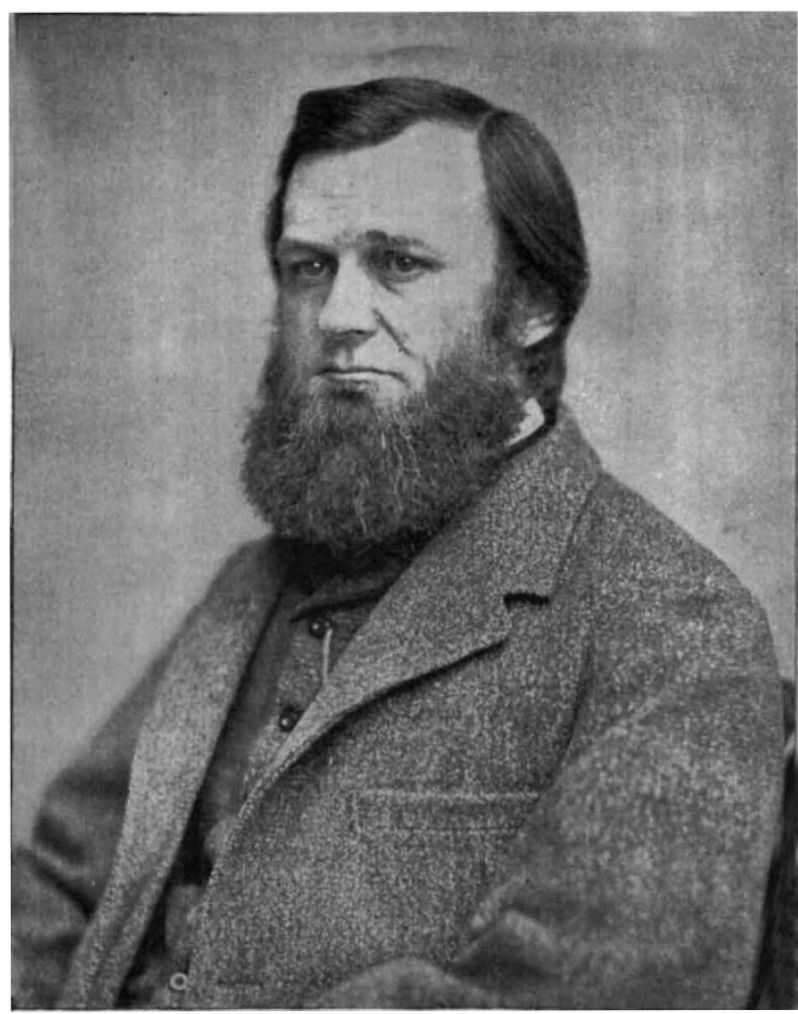

Fig. 4.-Spencer Fullerton Baird, Second Secretary of the Smithsonian Institution, $1878-87$.

of all systems of electric lighting and power. ${ }^{1}$ From the age of forty-seven to that of seventy-nine, he merged his life in that of the Institution. Prof. Asa Gray has shown so clearly the decp impression which he made upon the organisation while it was yet plastic, that I quote his words as the best explanation of the character of this element in its history :

" Some time before his appointment," writes Prof. Gray, "he had been requested by the members of the Board of Regents to examine the will of Smithson, and to suggest a plan of organisation by which the object of the bequest might, in his opinion, best be realised. He did so, and the plan he drew was in their hands when he was chosen Secretary. The plan was based on the conviction 'that the intention of the donor was to advance science by original research and publication; that the establishment was for the benefit of mankind generally, and that all unnecessary expenditure on local objects would be violations of the

1 Self-induction, and the intensity magnet, with which Henry and Faraday subsequently discovered magneto-electricity 
trust.' His 'Programme of Organisation' was submitted to the Board of Regents in the following year, was adopted as its governing policy, and has been reprinted in full or in part in almost every annual report. If the Institution is now known and praised throughout the world of science and letters, it is fulfilling the will of its founder and the reasonable expectations of the nation which accepted and established the trust, the credit is mainly due to the practical wisdom, and the catholic spirit, and the indomitable perseverance of its first Secretary, to whom the establishing act gave much power of shaping ends, which as rough-hewn by Congress were susceptible of various diversion. Henry took his stand on the broad and ample terms of the bequest, 'for the increase and diffusion of knowledge among men,' and he never narrowed his mind, and to locality gave what was meant for mankind. He proposed only one restriction, of wisdom and necessity, that in view of the limited means of the Institution, it ought not to undertake anything which could be done,

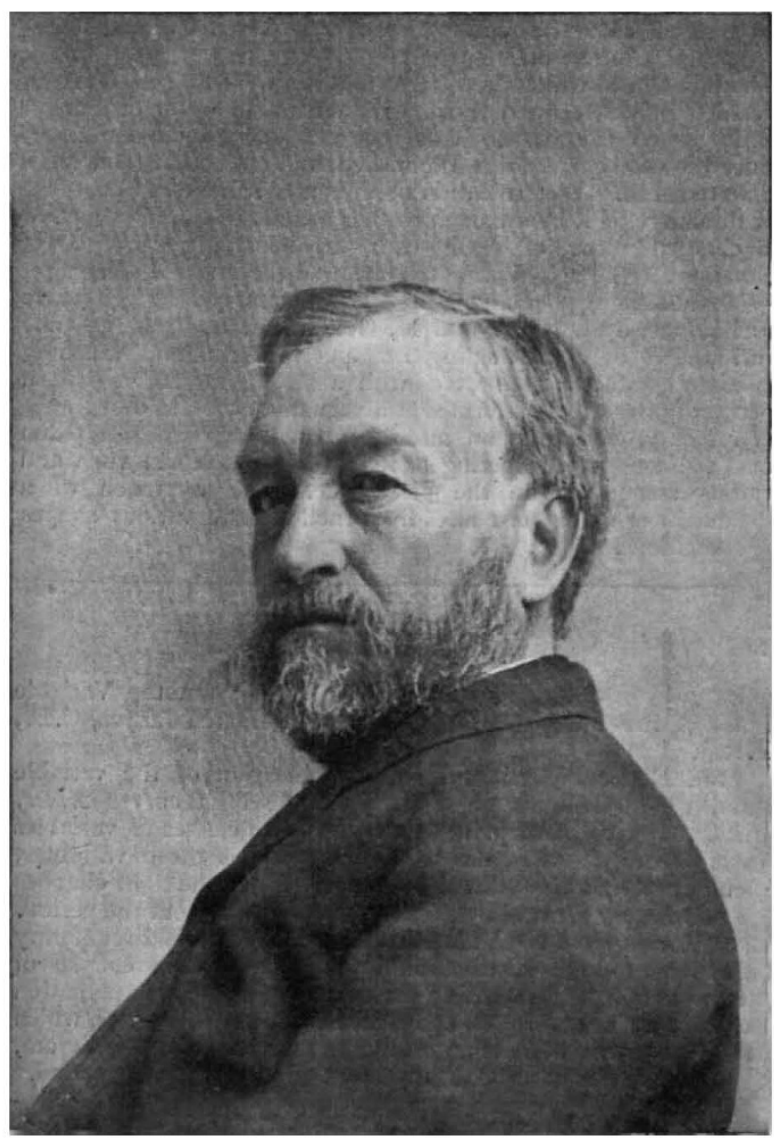

FIG. 5. - Samuel Pierpont Langley, Third Secretary of the Smithsonian Institution.

and well done, by other existing instrumentalities. So as occasion arose he lightened its load and saved its energies by giving over to other agencies some of its cherished work."

His statue, erected by order of Congress, stands in the Smithsonian Park.

Henry was succeeded in the office of Secretary by Prof. Spencer Fullerton Baird, then the leading authority on the mammals, birds, fishes, and reptiles of America, the founder of the U.S. Fish Commission, and of "public fish culture," elected in 1878 ; and he in his turn, by Samuel Pierpont langley, pre-eminent as physicist and astronomer, the inventor of the bolometer, the discoverer of a great portion of the infrared spectrum, and a high authority upon the physics of the atmosphere, elected in 1887 .

Each of the three Secretaries, in addition to his general administrative work, has made some feature of the general plan peculiarly his own. Secretary Henry gave especial attention to NO. I 368 , VOL. 53] the publications, the system of international exchanges, and the development of that great system of meteorological observation and weather prediction which has since become the Weather Bureau.

Secretary Baird continued the development of the museum, which had been under his special charge during his twentyseven years of service as assistant secretary, secured the erection of the new museum building, gave much attention to zoological and ethnological explorations and, in connection with his special work as Commissioner of Fisheries, secured the construction of the exploring ship Albatross, and carried on extensive investigations in American waters.

To Secretary Langley is due the establishment of the Nationa Zoological Park and the Astro-physical Observatory, renewed activity in the library and exchange work, and a new system of encouragement of original research in the physical as well as the biological sciences. Under his administration, also, important donations and bequests have been added to the permanent fund of the Institution. The limit of $1,000,000$ dols. which may by law be permanently deposited in the United States Treasury at 6 per cent., having nearly been reached, Congress has recognised the authority of the Institution to receive and administer other funds beyond this limit, thus making it possible for it to undertake the administration of financial trusts for any purpose within the scope of its general plan.

(To be continued.)

\section{UNIVERSITY AND EDUCATIONAL INTELLIGENCE.}

CAMBRIDGE. - A memorial is being circulated for the signature of members of the Senate, asking the Council of the Senate to sanction the formation of a Syndicate to consider on what conditions and with what restrictions, if any, women should be admitted to degrees in the University. It states that "for nearly fifteen years, since February I88I, the University has formally admitted the students of Girton and Newnham to its Honour examinations, and has practically co-operated in their instruction by permitting them to attend the lectures of its teaching staff, and to share the advantages of the University Library and other institutions. At the present time, eight out of the ten universities of Great Britain-viz., the University of London, the Victoria University, the new University of Wales, the four Scottish Universities, and the University of Durhamadmit women to degrees. The result is that the women to whom Cambridge now awards only certificates, feel the inferiority of their position in this respect as compared with that of women who pass the examinations of these other Universities. Further, a committee of the Council of the University of Oxford was appointed some months ago to consider the desirability of granting degrees to the women students at Oxford, whose position is now somewhat similar to that of the students of Girton and Newnham. There seems, in short, to be a danger lest Cambridge-which twenty years ago was acting as pioneer in the movement for extending the advantages of academic education to womenshould be actually the last to grant them the traditional and customary recognition of their work. The conditions under which degrees should be granted require very careful consideration. It is hoped that the syndicate of which we desire the appointment may be able to frame proposals which will command the assent of all who are interested in the academic education of women."

WE are informed that Mr. N. Busch has not been appointed Director of the Botanic Garden of the University of Dorpat, but assistant to Mr. N. Kuznetzov, formerly Assistant Secretary of the Imperial Russian Geographical Society, who has been also appointed Extraordinary Professor of Botany at the same University, instead of Dr. Russow retired.

DR. G. P. GRIMSBY has been appointed to the chair or Geology and Natural History in Washburn University; Dr. W. B. Rankin and C. F. W. McClure have been appointed to Professorships of Biology in the College of New Jersey; Dr. W. S. Strong has been called to the chair of Geology in Bates College, Lewiston, Maine ; and Dr. R. de Girard, privatdocent in Geology at the Zürich Polytechnikum, has been promoted to an Extraordinary Professorship. 